\title{
RAPD Markers Flanking the Are Gene for Anthracnose Resistance in Common Bean
}

\author{
Roberto A. Young and James D. Kelly \\ Department of Crop and Soil Sciences, Michigan State University, East Lansing MI, 48824 \\ Additional index words. Colletotrichum lindernufhianum, gene pyramiding, linkage, marker assisted selection, MAS, \\ Phaseolus vulgaris, polymerase chain reaction, PCR

\begin{abstract}
Incorporation of the dominant gene Are, of Middle American origin, into commercial cultivars of Phaseolus vulgaris $\mathbf{L}$., has been the main disease control strategy of plant breeders to limit the potential damage of Colletotrichum lindemuthianum (Sacc. \& Magnus.) Lams.-Scrib. A random amplified polymorphic DNA (RAPD) marker designated OQ4 $_{1440}$, generated by a 5'-AGTGCGCTGA-3' decamer primer, was found tightly linked in coupling with the Are gene. $\mathrm{OQ4}_{1440}$ mapped at $2.0 \pm 1.4$ centimorgans $(\mathrm{cM})$ from the Are allele in the Andean genetic background and at $5.5 \pm 2.3 \mathrm{CM}$ in the Middle American background. A second coupling phase RAPD marker B355 ${ }_{1000}$ generated by the 5'-GTATGGGGCT 3' primer mapped at $5.4 \pm 2.3 \mathrm{cM}$ from the Are allele in the Andean genetic background and at $7.7 \pm 2.7 \mathrm{CM}$ in the Middle American background. Based on a recombination distance of $7.0 \pm 1.9 \mathrm{cM}$ between the two markers, $\mathrm{OQ}_{1440}$ and $^{\mathrm{B355}} \mathrm{5}_{1000}$ RAPDs appear to flank the Are gene. The bracketing molecular markers allowed tagging of the Are allele with a selection fidelity of $99 \%$. Use of the $\mathrm{OQ4}_{1440}$ and $\mathbf{B 3 5 5 _ { 1 0 0 0 }}$ RAPD markers for marker-based selection will afford the opportunity to retain the Are anthracnose resistance gene in bean germplasm, as other epistatic resistance genes are characterized, and incorporated into contemporary bean cultivars.
\end{abstract}

Anthracnose, caused by Colletotrichum lindemuthianum, is a serious seedborne fungus capable of inducing complete yield loss in susceptible bean genotypes. Surveys in a wide range of production areas have identified several distinct races, suggesting extensive pathogenic variation on all continents (Pastor-Corrales and $\mathrm{Tu}$, 1989). In North America, reported races include alpha, alpha Brazil, beta, gamma, delta, epsilon, and lambda in Canada (Tu, 1992, 1994). Recently, Kelly et al. ( 1994) identified two new races of $C$. lindemuthianum in the United States, which are pathogenic on resistance genes currently deployed. The dominant allele at the Are locus, which confers resistance to alpha, beta, gamma, delta, epsilon, and lambda races of the fungus, was first found in a black bean from Venezuela, Cornell 49-242 (Mastenbroek, 1960) and has been used widely in North America and Europe as the main source of resistance against anthracnose (Fouilloux, 1979; Tu, 1992).

Marker-assisted selection (MAS), using molecular markers such as random amplified polymorphic DNA (RAPD) markers as the selectable marker, has the potential to be a useful breeding tool in common bean, where monogenic disease resistance genes have been tagged (Haley et al., 1993; Haley et al., 1994a, 1994b. 1994c; Johnson and Gepts, 1994; Johnson et al., 1995; Jung et al., 1994; Miklas et al., 1993). Conventional procedures for gene pyramiding are not practical for plant breeders due to epistatic interactions between resistance genes. Because pyramiding requires that epistatic and hypostatic genes be combined into a single genotype, breeders have no convenient way to select genotypes with a hypostatic gene without inoculating with different isolates of a

Received for publication 3 Apr. 1995. Accepted for publication 12 Sept. 1995. We acknowledge P.N. Miklas for developing the Middle American population; N. Weeden for the initial identification of the linked B355 Afanador for assisting with disease screening. This research was supported in part by the grant DAN 1310-G-SS-6008-00 from the US AID Bean/Cowpea Collaborative Research Support Program and the Michigan Agricultural Experiment Station. Support for R.A.Y, from Latin American Scholarship Program of American Universities (LASPAU) is recognized, The cost of' publishing this paper was defrayed in part by the payment of page charges. Under postal regulations, this paper therefore must be hereby marked advertisement solely to indicate this fact. pathogen or test crossing back to a susceptible genotype. However the identification of molecular markers tightly linked to resistance genes allows indirect selection because the expression of the marker is not masked by epistatic interactions. The identification of a number of RAPD markers in common bean now permits gene pyramiding for disease resistance For example, RAPD markers can be used to pyramid three rust (Uromyces appendiculatus) resistance alleles ( $U p_{2}, U r-3, \mathrm{~B}-190$; Kelly, 1995) with other epistatic resistance alleles from the plant introduction collection (Johnson et al., 1995). Similar pyramiding opportunities for MAS have been suggested in breeding for resistance to bean common mosaic virus (BCMV), since the I, bc-3 gene combination affords resistance to all known strains of BCMV (Haley et al., 1994b). Efficiency in selection can be improved by using a second marker either linked in repulsion with the resistance gene (Haley et al., 1994a) or linked in coupling but flanking the allele of interest (Tanksley, 1983).

Two gene pools exist in P. vulgaris, the Middle American and the Andean (Gepts and Bliss, 1985; Gepts et al., 1986) and crosses between these have been utilized to exploit breeding for anthracnose resistance in different bean seed and pod types. RAPD markers linked to genes introgressed from germplasm derived from a different gene pool appear to have lower recombinational frequencies and apparent tighter linkages than recombinational distances measured between the same RAPD linked to the resistance gene in the same gene pool (Haley et al., 1994b). Brown et al. ( 1989) demonstrated that linkage between traits can vary depending on the populations studied and the genetic similarity between parents. Because recombinational frequencies may be underestimated in wide crosses (Paterson et al., 1990), map distances based on figures from such crosses may not represent the actual distance between markers and genes in more related genetic backgrounds with which breeders most frequently work.

The objectives of the present research were to find a RAPD marker linked to the Middle American Are allele, and compare its utility with another previously characterized marker $\left(\mathrm{B} 355_{1000}\right)$ in Andean and Middle American bean populations. Comparison of recombinational distance between RAPD markers and the Are allele in common bean gene pools were analyzed. 


\section{Materials and Methods}

Genetic material. Two groups of nearly isogenic lines (NILs) were used to screen for RAPD markers linked to the Middle American Are gene in different genetic backgrounds. A pedigree generated $\left(F_{11}\right)$ inbred line (designated K86002) heterogeneous for the Are locus was the source of NILs in the Andean genetic background. The kidney bean line K86002 was originally derived from introgression of the Are gene through backcrossing (CN49242/ $4 *$ Montcalm//Charlevoix). The development of NILs from advanced heterogeneous lines has been described previously (Haley et al., 1994c). The DNA from K86002 lines, homozygous dominant and homozygous recessive for the Are locus respectively, constituted the contrasting NIL pair in the Andean genetic background. The other NIL pair was obtained from a $\mathrm{F}_{2}$ population (A4512) derived by crossing two nearly-isogenic Middle American cultivars (Ex Rico 23/OAC Rico; Beversdorf, 1983), which differed for the presence (OAC Rico) and absence (Ex Rico 23) of the Are gene. Bulked segregant analysis (Michelmore et al., 1991) was used to prepare the DNA bulk-NILs from the A4512 population in the Middle American genetic background. The two contrasting DNA pairs (one pair Andean and one pair of Middle American origin) were screened with random decamer primers to identify RAPD markers linked to the Are allele. Progeny of $108 \mathrm{~F}_{2}$ $\left(103 \mathrm{~F}_{2: 3}\right.$ ) individuals from the Andean (K86002) and $109 \mathrm{~F}_{2}(104$ $\mathrm{F}_{2: 3}$ ) individuals from the Middle American (A4512) crosses were used as mapping populations.

Disease evaluations. Parental material used as sources of DNA for primer screening were first genotyped for the Are locus by inoculating with the appropriate race of $C$. lindemuthianum. The choice of different races of $C$. lindemuthianum to screen for the Are resistance gene was based on differential disease reaction of germplasm from each gene pool. To discriminate effectively between resistant and susceptible genotypes in the segregating $F_{2}$ and $\mathrm{F}_{2: 3}$ populations, the beta race was used to screen the $\mathrm{K} 86002$ population and delta race was used to screen the A4512 population. Progeny tests of at least 11 to a maximum of 18 plants from each $\mathrm{F}_{2: 3}$ family from both mapping populations were carried out to confirm the disease expression of $\mathrm{F}_{2}$ individuals and separate homozygous Are Are from heterozygous Are are genotypes. All pathogen inoculations were conducted using a suspension of $1.2 x$ $10^{-6} \mathrm{spores} / \mathrm{ml}$. The first incompletely expanded trifoliate leaf of 15 to 18 day old $\mathrm{F}_{2}$ plants was inoculated on the lower and upper leaf surfaces. Spore suspension was applied with an artist's camel-hair paint brush. Conversely, $\mathrm{F}_{2: 3}$ families were spray inoculated with the spore suspension on the abaxial and stem surface of unifoliate leaves (10- to 12-day-old seedlings). Different inoculation meth- ods were used because $\mathrm{F}_{2}$ (particularly susceptible individuals), unlike $F_{2: 3}$ plants, were saved for $F_{3}$ seed production and leaf tissue sampling for DNA extraction. Inoculated plants were placed in a mist chamber $(100 \% \mathrm{RH})$ at $22-25 \mathrm{C}$ for $48 \mathrm{~h}$, then transferred to the greenhouse. Disease ratings were made 7 days postinoculation. Disease reactions were recorded as resistant $(\mathrm{R})$ for those plants with no visible disease symptoms of anthracnose, and susceptible (S) for those plants with presence of enlarged lesions or sunken cankers on the lower side of the leaf or hypocotyl.

$R A P D$ analysis. Before inoculation with $C$. lindemuthianum, tissue was collected for DNA extraction from young primary leaves (4 to 7 days postemergence) from greenhouse-grown plants. Two discs of leaf tissue were cut by clipping the leaf with a $1.5-\mathrm{ml}$ microcentrifuge tube. A simple and quick extraction method developed by Afanador et al., (1993) was used for DNA extraction. The extracted DNA was standardized to a uniform concentration (10 $\mathrm{ng} \cdot \mathrm{\mu l}^{-1}$ ) using DNA fluorometry (Hoefer TKO 100, Hoefer Scientific, San Francisco).

The polymerase chain reaction (PCR) cycling profile consisted of 3 cycles of $1 \mathrm{~min} / 94 \mathrm{C}, 1 \mathrm{~min} / 35 \mathrm{C}, 2 \mathrm{~min} / 72 \mathrm{C} ; 34$ cycles of 10 $\mathrm{sec} / 94 \mathrm{C}, 20 \mathrm{sec} / 40 \mathrm{C}, 2 \mathrm{~min} / 72 \mathrm{C}$; 1 cycle of $5 \mathrm{~min} / 72 \mathrm{C}$; $1 \mathrm{sec}$ autosegment extension (for extension phase of 34-cycle portion of PCR). Amplification was carried out in a DNA thermal cycler (model 480; Perkin Elmer Cetus, Norwalk, Corm.). Description of the PCR reactions have been reported previously (Haley et al., 1993; Miklas et al., 1993). About $10 \mathrm{ng}$ of genomic DNA template and $10 \mathrm{ng}$ of a decamer primer (Operon Technologies, Alameda, Calif.) were combined in an 18.8- $\mu$ reaction, containing 2 units of Stoffel Fragment Polymerase (Perkin Elmer Cetus). Amplified DNA fragments were resolved by electrophoresis in $1.4 \%$ agarose gel containing $0.5 \mu \mathrm{g} \cdot \mathrm{ml}^{-1}$ ethidium bromide, $40 \mathrm{~mm}$ Tris-acetate, and $1 \mathrm{~mm}$ EDTA. Polymorphisms were scored as either presence or absence of a band (visualized using UV light) between bulked DNA pairs with or without the Are allele, respectively. Prior to screening the mapping populations, DNA from other known resistant and susceptible genotypes were used to confirm potential RAPD- Are locus linkages.

Linkage with a second RAPD marker, identified by Weeden (personal communication) in recombinant inbred populations of Andean snap bean germplasm segregating for the Are gene, was studied in the same two $\mathrm{F}_{2}$ populations $\mathrm{K} 86002$ and A4512. The second RAPD marker was obtained using the B355 primer 5'GTATGGGGCT-3' which amplified a 1000-bp fragment linked in coupling with the Are allele. The marker symbol B355 is the identification used by the Univ. of British Columbia to describe the 10-mer primer. The RAPD marker $\mathrm{B} 355_{1000}$ was identified using the PCR protocol for DNA amplification recommended by

Table 1. Two-point chi-square analyses and linkage estimates for marker loci $\left(\mathrm{OQ}_{1440}\right.$ and $\left.\mathrm{B} 355_{1000}\right)$ and thanthracnose resistant Are allele

\begin{tabular}{|c|c|c|c|c|c|c|}
\hline Population $^{2}$ & $\begin{array}{l}\text { Locus } \\
\text { tested }\end{array}$ & $\begin{array}{l}\text { Expected } \\
\text { ratio }\end{array}$ & $\begin{array}{l}\text { Observed } \\
\text { frequency }\end{array}$ & $\chi^{2}$ & Probability & $\begin{array}{c}\mathrm{cM} \\
(\mathrm{r} \pm \mathrm{SE})\end{array}$ \\
\hline Middle American & Are/ OQ4 $4_{1440}$ & $3: 6: 3: 1: 2: 1$ & $29: 39: 0: 1: 4: 31$ & 83.7 & 0.00 & $5.5 \pm 2.3$ \\
\hline Andean & Are/ OQ4 ${ }_{1440}^{1440}$ & $3: 6: 3: 1: 2: 1$ & $26: 54: 1: 0: 1: 21$ & 91.5 & 0.00 & $2.0 \pm 1.4$ \\
\hline Middle American + Andean & Are/ OQ4 ${ }_{1440}$ & $3: 6: 3: 1: 2: 1$ & $55: 93: 1: 1: 5: 52$ & 173.7 & 0.00 & $3.9 \pm 1.4$ \\
\hline Middle American & Are/ B $355_{1000}$ & $3: 6: 3: 1: 2: 1$ & $29: 41: 4: 1: 2: 27$ & 73.0 & 0.00 & $7.7 \pm 2.7$ \\
\hline Andean & Are/ B355 & $3: 6: 3: 1: 2: 1$ & $27: 53: 4: 0: 1: 18$ & 74.7 & 0.00 & $5.4 \pm 2.3$ \\
\hline Middle American + Andean & Are/ B355 & $3: 6: 3: 1: 2: 1$ & $56: 94: 8: 1: 3: 45$ & 147.9 & 0.00 & $6.6 \pm 1.8$ \\
\hline Middle American & $\mathrm{OQ} 4_{1440} / \mathrm{B} 355_{1000}$ & $9: 3: 3: 1$ & $67: 2: 7: 28$ & 67.3 & 0.00 & $8.3 \pm 2.9$ \\
\hline Andean & OQ4 ${ }_{1440} / \mathrm{B} 355_{1000}$ & $9: 3: 3: 1$ & $80: 1: 4: 18$ & 74.7 & 0.00 & $5.4 \pm 2.3$ \\
\hline Middle American + Andean & $\mathrm{OQ} 4_{1440} / \mathrm{B} 355_{1000}$ & $9: 3: 3: 1$ & $147: 3: 11: 46$ & 141.6 & 0.00 & $7.0 \pm 1.9$ \\
\hline
\end{tabular}

${ }_{\bar{z}}^{\bar{A}}$ Anthracnose evaluation of Middle American (Ex Rico 23/OAC Rico, A4512), and Andean (K86002 S/ K86002 R) populations conducted on $\mathrm{F}_{2: 3}$ progenies. Linkage analysis based on 1:2:1 genotypic segregation ratio for the Are locus and 3: 1 ratio for the OQ $4_{1440}$ and B355 $5_{1000}$ RAPD markers. 
$\begin{array}{lllllllllllll}1 & 2 & 3 & 4 & 5 & 6 & 7 & 8 & 9 & 10 & 11 & 12 & 13\end{array}$

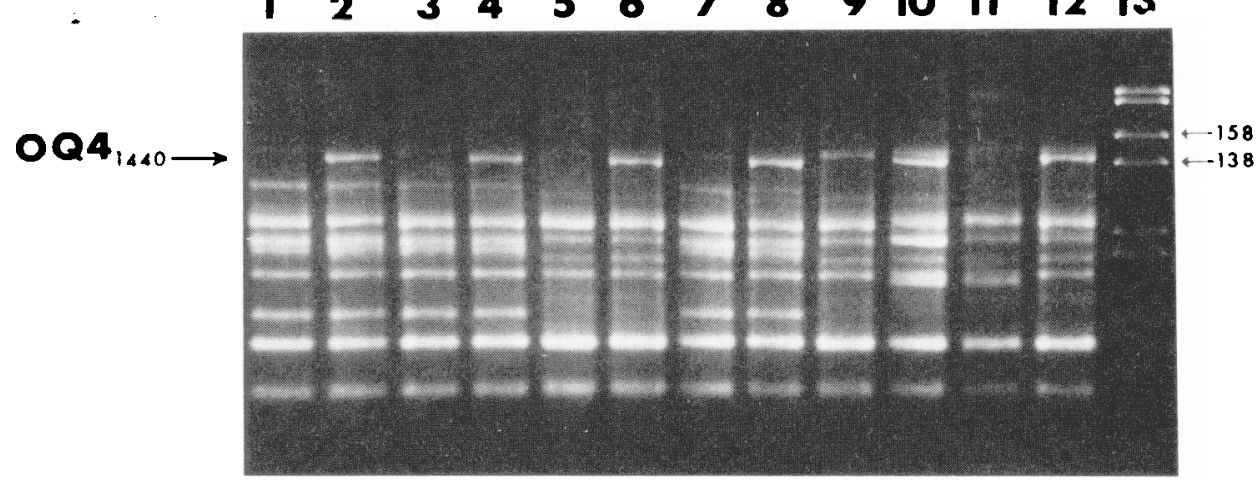

Fig. 1. Amplification of genomic DNA using OQ $4_{1440}$ RAPD marker. (1) Anthracnosesusceptible Andean parent, (2) anthracnoseresistant Andean parent, (3) susceptible Andean $\mathrm{F}_{2}$ individual, (4) resistant Andean $\mathrm{F}_{2}$ individual, (5) anthracnose-susceptible Middle American DNA bulk, (6) anthracnose-resistant Middle American DNA bulk, (7) susceptible Andean cultivar (Montcalm), (8) resistant Andean cultivar (Isles), (9) anthracnose-susceptible Middle American parent (Ex Rico 23), (10) anthracnoseresistant Middle-American parent (OAC Rico), (11) anthracnose-susceptible Middle American cultivar (Mayflower), (12) anthracnose-resistant Middle American cultivar (Harokent), (13) molecular weight marker ( $\lambda$ Hind III/ EcoR1; size of bands indicated in $\mathrm{bp}$ )
GibcoBRL. The cycling profile consisted of 35 cycles of $1 \mathrm{~min}$ each /at 92, 35, and $72 \mathrm{C}$ using 1.0 unit of Taq DNA polymerase (GibcoBRL) as the thermal stable enzyme.

A simple dominant transmission of the Are gene and the putative linked RAPD markers were analyzed by chi square. The recombination frequency between a RAPD marker and the Are allele and between OQ $4_{1440}$ and B355 $5_{1000}$ RAPDs was calculated using Linkage ${ }^{-1}$ (Suiter et al., 1983) and Mapmaker (Lander et al., 1987). Linkage estimates between loci are expressed in centimorgans (cM) as they were calculated using Kosambi's function by the Linkage-1 computer program.

\section{Results}

A total of 346 random decamer primers were screened against the contrasting DNA combinations of resistant and susceptible genotypes from Middle American and Andean origin. Polymorphisms within at least one of the DNA pairs, were generated by about $32 \%$ of the primers, while only $8 \%$ of the primers tested produced polymorphic loci in both DNA pairs. The number of false positives generated between DNA pairs alone was relatively high, but once they were compared to DNA controls, the majority of them were eliminated. RAPD variability generated within the Middle American (A4512) bulk-NILs was less frequent (13\%) than that found within the Andean (K86002) NILs (1970). Different levels of polymorphisms within Middle American versus within Andean gene pools have been reported by Haley et al. (1994d).

Identification of RAPD markers. Five putatively linked RAPD markers, two apparently associated in coupling, and three in repulsion phase with the dominant Are allele, were identified across both populations. These RAPD markers were assayed for co-segregation with $\mathrm{F}_{2}$ genotypes characterized as resistant and susceptible in the two segregating populations Only one RAPD marker, generated by a 5'-AGTGCGCTGA-3' decamer primer and designated $\mathrm{OQ}_{1440}$,- ' $\mathrm{O}$ ' for the source of the primer (Operon Technologies), Q4 for the specific kit (Q) and primer number (4), and 1440 for the size (bp) of the polymorphic fragment; was found to be tightly linked with the Are allele. The OQ4 ${ }_{1440}$ mapped at 2.0 $\pm 1.4 \mathrm{cM}$ in the Andean genetic background and at 5.5 $\pm 2.3 \mathrm{CM}$ in Middle American background from the Are allele (Table 1). A second coupling phase RAPD marker B355 $5_{1000}$ mapped at $5.4 \pm 2.3$ $\mathrm{CM}$ in the Andean genetic background and at $7.7 \pm 2.7 \mathrm{CM}$ in the Middle American background from the Are allele. Based on recombination distances of $7.0 \pm 1.9 \mathrm{CM}$ between the two markers across both gene pools $(5.4 \pm 2.3 \mathrm{CM}$ in the Andean population, and $8.3 \pm 2.9 \mathrm{cM}$ in the Middle American population), OQ4 $4_{1440}$ and B 355 1000 RAPD markers appear to flank the Are allele (Table 1). Differences in recombination values were observed between populations, but these were not statistically significant $(P \leq 0.05)$ for either marker. In each population, segregation ratios consistent with dominant monogenic inheritance were observed for the OQ $4_{1440}$ and B $355_{1000}$ RAPD markers and the dominant Are allele (Table 2). The amplification of the 1440 bp DNA fragment by the OQ4 ${ }_{1440}$ RAPD marker, was scored across a number of individuals with known genotype at the Are locus (Fig. 1). The presence and absence of the RAPD marker was associated with resistant and susceptible phenotypes of $\mathrm{F}_{2}$ individuals and commercial cultivars possessing or lacking the Are gene respectively.

Selection efficiency. Efficiency of indirect selection, based on actual observations, for the Are locus using OQ4 ${ }_{1440}$ and B355 $5_{1000}$ RAPD markers was analyzed within and across gene pools (Table 3). Selection efficiency is defined here as the ability of a RAPD marker, used alone or a combination of both markers, for effectively distinguish between resistant (Are Are and Are are) and susceptible (are are) $\mathrm{F}_{2}$ individuals based on the marker phenotype

Table 2. Chi-square analysis for $\mathrm{OQ} 4_{140}$ and $\mathrm{B} 355_{1000}$ RAPD markers and the Are allele segregating in Middle American and Andean $\mathrm{F}_{2}$ and $\mathrm{F}_{2: 3}$ populations.

\begin{tabular}{lcccccc}
\hline \hline Population & zocus & $\begin{array}{c}\text { Leneration } \\
\text { tested }\end{array}$ & $\begin{array}{c}\text { Expected } \\
\text { ratio }\end{array}$ & $\begin{array}{c}\text { Observed } \\
\text { frequency }\end{array}$ & $\chi^{2}$ & Probability \\
\hline Middle American & Are & $\mathrm{F}_{2}$ & $3: 1$ & $78: 31$ & 0.52 & 0.47 \\
Middle American & Are & $\mathrm{F}_{2: 3}$ & $1: 2: 1$ & $30: 43: 31$ & 3.14 & 0.21 \\
Andean & Are & $\mathrm{F}_{2}$ & $3: 1$ & $86: 22$ & 1.00 & 0.32 \\
Andean & Are & $\mathrm{F}_{2: 3}$ & $1: 2: 1$ & $26: 55: 22$ & 0.79 & 0.67 \\
Middle American & $\mathrm{OQ}_{1440}$ & $\mathrm{~F}_{2}$ & $3: 1$ & $73: 36$ & 3.33 & 0.07 \\
Middle American & $\mathrm{B355}_{1000}$ & $\mathrm{~F}_{2}$ & $3: 1$ & $79: 30$ & 0.25 & 0.62 \\
Andean & $\mathrm{OQ4}_{1440}$ & $\mathrm{~F}_{2}$ & $3: 1$ & $86: 22$ & 1.00 & 0.32 \\
Andean & $\mathrm{B355}_{1000}$ & $\mathrm{~F}_{2}$ & $3: 1$ & $89: 19$ & 2.78 & 0.10 \\
\hline
\end{tabular}

${ }^{\bar{z}}$ Middle American (Ex Rico 23/OAC Rico, A4512); Andean (K86002 WK86002 R). 
Table 3. Efficiency of RAPD markers linked to the Are allele for marker selection within and across common bean gene pools,

\begin{tabular}{|c|c|c|c|c|c|c|}
\hline \multirow[b]{3}{*}{$\begin{array}{l}\text { RAPD } \\
\text { marker(s) }\end{array}$} & \multicolumn{6}{|c|}{ Gene pools" } \\
\hline & \multicolumn{2}{|c|}{ A } & \multicolumn{2}{|c|}{ MA } & \multicolumn{2}{|c|}{$\mathrm{A}+\mathrm{MA}$} \\
\hline & $\begin{array}{l}\text { No. of } \\
\text { recomb. }\end{array}$ & $\begin{array}{c}\text { Selection } \\
\text { efficiency } \\
(\%)\end{array}$ & $\begin{array}{l}\text { No. of } \\
\text { recomb. }\end{array}$ & $\begin{array}{c}\text { Selection } \\
\text { efficiency } \\
(\%)\end{array}$ & $\begin{array}{l}\text { No. of } \\
\text { recomb. }\end{array}$ & $\begin{array}{l}\text { Selection } \\
\text { efficiency } \\
(\%)\end{array}$ \\
\hline$\overline{\mathrm{OQ}} 4_{1440}$ & 2 & 98.1 & 5 & 95.2 & 7 & 96.6 \\
\hline $\mathrm{B} 355_{10000}^{1400}$ & 5 & 95.1 & 7 & 93.3 & 12 & 94.2 \\
\hline $\mathrm{OQ} 4_{1440}+\mathrm{B} 355_{10000}$ & 1 & 99.0 & 2 & 98.1 & 3 & 98.6 \\
\hline
\end{tabular}

${ }^{\mathrm{z}} \mathrm{A}=$ Andean (K86002 S/K86002 R): MA= Middle American (Ex Rico 23/OAC Rico, A4512).

as selection criteria. Since OQ4 ${ }_{1440}$ RAPD mapped tighter to the Are allele than the $\mathrm{B} 355_{1000} \mathrm{RAPD}$, efficiency of indirect selection for resistant and susceptible $\mathrm{F}_{2}$ individuals was higher when the OQ4 ${ }_{1440}$ marker was used alone, regardless of genetic background (95.2\% vs. $93.3 \%$ in Middle American and $98.1 \%$ vs. $95.1 \%$ in Andean genetic background). However when both RAPD markers were utilized together, selection efficiency within and across gene pools increased to $98.6 \%$ in the combined Middle American and Andean populations. The largest improvement in selection efficiency was observed using B355 1000 alone $(93.3 \%)$ when compared to the combination of $\mathrm{OQ} 4_{140}+\mathrm{B} 355_{1000}$ RAPD markers $(98.1 \%)$ in the Middle American genetic background.

\section{Discussion}

Identification and usefulness of RAPD markers. In plant breeding, marker loci tightly linked to genes of interest are needed for implementation of MAS strategies for gene introgression. The most desirable markers are those that exhibit tight linkage $(\leq 5 \mathrm{cM}$; Tanksley, 1983) with the resistance genes. However, many studies restrict the application of markers to specific genetic population, so the usefulness of a linked marker is not always demonstrated across a range of genetic backgrounds. In common bean, RAPD markers may be gene pool specific and of limited value in selecting for resistance genes in the same genetic background from which the genes are indigenous. This limitation was demonstrated with the RAPD marker linked to the $U p_{2}$ gene which could not be used for selection for rust resistance in the Andean gene pool from which the $U p_{2}$ gene originated (Miklas et al., 1993). Therefore the value of that marker was restricted to the Middle American gene pool. This result is in contrast to that for the RAPD marker OI19 ${ }_{460}$ linked to the Middle American B- 190 gene which can be used in all gene pools regardless of origin of the resistance gene (Haley et al., 1993). Similarly RAPD markers associated with the rust resistance gene $U r-3$ (Haley et al., 1994c) and the I gene for BCMV resistance (Haley et al., 1994b) have broad application across gene pools and genotypes. A RAPD marker found linked to the Are allele in Andean, snap bean, population was reported by AdamBlondon et al. (1994). Since this molecular marker was not tested across different genetic backgrounds its usefulness for introgressing the Are gene into Middle American germplasm using MAS remains to be confirmed.

The use of DNA from the two distinct genetic populations (Andean and Middle American) in the initial screening of primers, enabled us to identify a gene pool nonspecific RAPD marker $\left(\mathrm{OQ} 4_{1440}\right)$ for the Are gene. The second RAPD marker (B355 $\left.{ }_{1000}\right)$ linked in coupling with Are allele, exhibited similar differential recombination between the two populations. The linkage distances were greater than those found for the OQ4 $4_{140}$ marker but since the differences were non significant, the $\mathrm{B} 355_{1000}$ marker is equally robust as a too] for indirect selection in populations of bean derived from the two gene pools. The linkage distance between the two markers is greater than the distance of either individual marker to the Are gene in both populations. Although the actual linkage distance is less than the sum of the individual distances between individual markers and the gene, the data clearly suggest that the markers flank the Are locus.

Selection efficiency and recombination frequency. Flanking markers have been shown to be more efficient in selection for a trait of interest (Tanksley, 1983). Combining marker data from $207 \mathrm{~F}_{2}$ individuals belonging to both segregating populations, the bracketing RAPD markers were able to select for the Are allele with 98.6\% efficiency. Based on recombination frequency of the these two RAPD markers the theoretical selection fidelity reaches $99.7 \%$. The benefit of bracketing markers for marker-assisted selection is not fully appreciated when individual markers are tightly linked to the gene of interest, which is the case of the present study. However with looser linkages, scoring for flanking markers would show greater selection efficiency over single (closely linked) marker selection.

The introgression of the Are gene into the Andean gene pool from Middle American germplasm represents a wide cross. Haley et al., ( 1993), showed that genes from the Middle American gene pool appear to exhibit tighter linkages with markers when measured in the Andean genetic background. A similar trend has been observed with Andean resistance genes when studied in Middle American segregating populations (Miklas et al., 1993). Lower recombination values between the Are allele and both RAPD markers were both expected and observed in the Andean mapping population. Although differences in recombination frequencies were not statistically supported, it is noteworthy that the two described RAPD markers were developed independently and both showed trends similar to previously reported observations. Recombination has specific mechanisms that are not clearly understood. Environmental effects may play a role in different recombination frequencies observed between populations. The present study was not designed to distinguish genotypic from environmental influences on estimates of recombination values. However the apparent difference in linkage between populations derived from the two gene pools might suggest that some form of recombinational suppression is occurring in wide crosses of common bean. A larger population size and/or a larger sample of crosses representing both gene pools might be needed to determine differences in recombination distance between germplasm pools. Any difference in the recombination value between gene pools of $P$. vulgaris might suggest the need to conduct mapping studies in populations in which breeders are actively working. Developing genetic maps using wide crosses may allow the mapping of a number of traits but may be of limited value to applied plant breeders interested in using markers to introgress an agronomically useful trait. Until 
linkages are generated and tested among related materials, mapbased breeding will probably be restricted to the introgression of foreign genes.

Application of RAPD markers. The occurrence of two new races of C. lindemuthianum in North America has put in jeopardy the long-term strategy of relying on single gene resistance for controlling bean anthracnose (Kelly et al., 1994; Tu, 1994). Race 73 and alpha-Brazil overcome the resistance conferred by the Are gene, and race 7 is virulent on genotypes carrying the $A$ gene. Since the $A$ gene conditions resistance to races 73 and alpha-Brazil, Phaseolus breeders now need to pyramid the Are and $A$ genes into new cultivars as the only effective means of conferring resistance to all current North American races of $C$. lindemuthianum. With the characterization of additional anthracnose resistance genes (Pastor-Corrales et al., 1994), MAS offers bean breeders a viable alternative for developing cultivars with pyramided resistance genes as a means of increasing the durability of anthracnose resistance in common bean. As new broadly based epistatic anthracnose resistance genes are being introgressed into commercial bean cultivars, using more virulent races of the pathogen, the O Q $4_{1440}$ and B355 1000 RAPD markers will be used to ensure the retention of the hypostatic Are gene in these materials. Since selection for the hypostatic Are gene will be dependent on linked markers in the absence of test crosses and multiple anthracnose inoculations, flanking markers offer a significantly increased level of efficiency over single closely linked markers for marker based selection. Thus, long term durable anthracnose resistance in common bean could be provided through the pyramiding of resistance genes using these RAPD markers.

\section{Literature Cited}

Adam-Blondon, A. F., M. Sevignac, H. Bannerot, and M. Dron. 1994. SCAR, RAPD and RFLP marker linked to a dominant gene (Are) conferring resistance to anthracnose in common bean. Theor. Appl. Genet. 88:865-870.

Afanador, L. K., S.D. Haley, and J.D. Kelly. 1993. Adoption of a 'miniprep' DNA extraction method for RAPD marker analysis in common bean (Phaseolus vulgaris). Annu. Rpt. Bean Improv. Coop. 36:10-1 I. Beaversdorf, W.D. 1983. OAC Rico field bean. Can. J. Plant Sci. 64:753755.

Brown, A. H. D., J. Lawrence, M. Jenkin, J. Douglass, and E. Gregory. 1989. Linkage drag in backcross breeding in barley. J. Hered. 80(3):234 239.

Fouilloux, G. 1979. New races of bean anthracnose and consequences on our breeding programs, p. 221-235 In: H. Maraite and J.A. Meyer (eds.), Intl. Symp. Dis. Trop. Food Crops.

Gepts, P. and F.A. Bliss. 1985. F, hybrid weakness in the common bean. J. Hered. 76:447-450.

Gepts, P., T.C. Osborn, K. Rashka, and F.A. Bliss. 1986. Phaseolin protein variability in wild forms and landraces of the common bean (Phaseolus vulgaris): Evidence for multiple centers of domestication. Econ. Bet. 40:451-468.

Haley, S. D., P.N. Miklas, J.R. Stavely, J. Byrum, and J.D. Kelly. 1993. Identification of RAPD markers linked to a major rust resistance gene block in common bean. Theor. Appl. Genet. 86:505-512.

Haley, S. D., L.K. Afanador, and J.D. Kelly. 1994a. Selection for monogenic resistance traits with coupling and repulsion-phase RAPD markers, Crop Sci, 34: 1061-1066.

Haley, S.D., L.K. Afanador, and J.D. Kelly. 1994b. Identification and application of a random amplified polymorphic DNA marker for the $I$ gene (Potyvirus resistance) in common bean. Phytopathology 84: 157160.

Haley, S. D., L.K. Afanador, P.N. Miklas, J.R. Stavely, and J.D. Kelly. 1994c, Heterogeneous inbred populations are useful as sources of nearisogenic lines for RAPD marker localization. Theor. Appl. Genet. 88:337-342.

Haley, S. D., P.N. Miklas, L.K. Afanador, and J.D. Kelly. 1994d. Random Amplified Polymorphic DNA (RAPD) marker variability between and within gene pools of common bean. J. Amer. Soc. Hort. Sci. 119: 122125.

Johnson, E., P.N. Miklas, J.R. Stavely, and J.C. Martinez-Cruzado. 1995. Coupling- and repulsion-phase RAPDs for marker-assisted selection of the PI 181996 rust resistance in common bean. Theor. Appl. Genet. 90:659-664.

Johnson, W.C. and P. Gepts. 1994. Two new molecular markers linked to bc-3. Ann. Rpt. Bean Impov. Coop, 37:206-207.

Jung, G., D.P. Coyne, P.W. Skroch, J. Nienhuis, E. Amaud-Santana, J. Bokosi, S.M. Kaeppler, and J.R. Steadman. 1994. Construction of a genetic linkage map and locations of common blight, rust resistance and pubescence loci in Phaseolus vulgaris L. using RAPD markers. Annu. Rpt. Bean Improv. Coop. 37:37-38.

Kelly, J. D., L.K. Afanador, and L.S. Cameron. 1994. New races of Colletotrichum lindemuthianum in Michigan and implications in dry bean resistance breeding. Plant Dis. 78:892-894.

Ken y, J.D. 1995. Use of random-amplified polymorphic DNA markers in breeding for major resistance to plant pathogens. HortScience 30:461 465.

Lander, E. S., P. Green, J. Abrahamson, A. Barlow, M.J. Daly, S.E. Lincoln, and L. Newburgh. 1987. MAPMAKER: An interactive computer package for constructing primary genetic linkage maps of experimental and natural populations. Genomics 1: 174-181.

Mastenbroek, C. 1960. A breeding programme for resistance to anthracnose in dry shell haricot beans, based on a new gene. Euphytica 9(2): 177-184.

Michelmore, R. W., I. Paran, and R.V. Kesseli. 1991. Identification of markers linked to disease resistance genes by bulked segregant analysis: A rapid method to detect markers in specific genomic regions using segregating populations. Proc. Natl. Acad. Sci. USA 88:9828-9832.

Miklas, P. N., J,R. Stavely, and J.D. Kelly. 1993. Identification and potential usc of a molecular marker for rust resistance in common bean. Theor. Appl. Genet. 85:745-749.

Pastor-Corrales, M.A. and J.C, Tu, 1989. Anthracnose, p. 77-104 in: Bean production problems in the tropics. H.F Schwartz and M.A PastorCorrales (eds.). Centro Internacional de Agricultura Tropical, Cali, Colombia.

Pastor-Corrales, M. A., O.A. Erazo, E.I. Estrada, and S.P. Singh. 1994. Inheritance of anthracnose resistance in common bean accession G 2333. Plant Dis. 78:959-962.

Paterson, A. H., J.W. DeVerna, B. Lanini, and S.D. Tanksley. 1990. Fine mapping of quantitative trait loci, using selected overlapping recombinant chromosomes, in an interspecific cross of tomato. Genetics 124:735742.

Suiter, K. A., J.F. Wendel, and J.S. Case. 1983. Linkage-1: A PASCAL computer program for the detection and analysis of genetic linkage. J. Hered. 74:203-204.

Tanksley, S.D, 1983. Molecular markers in plant breeding. Plant. Mol. Biol. Rpt. 1(1):3-8.

Tu, J.C. 1992. Colletotrichum lindemuthianum on bean. Population dynamics of the pathogen and breeding for resistance, p. 203-224. In: J.A. Bailey and M.J. Jeger (eds.). Colletotrichum - Biology, pathology and control. C.A.B. International, Wallingford, U.K.

Tu, J.C. 1994. Occurrence and characterization of the alpha-Brazil race of bean anthracnose (Colletotrichum lindemuthianum) in Ontario. Can. J. Plant Pathol. 16:129-131. 